\title{
MANAJEMEN PENGELOLAAN ZAKAT PRODUKTIF DI YAYASAN ASH SHAHWAH (YASA) MALANG
}

\author{
Moh. Toriquddin dan Abd. Rauf \\ Fakultas Syariah UIN Maulana Malik Ibrahim Malang \\ Email:moh.toriquddin@gmail.com
}

\begin{abstract}
Abstrak
This research aims at describing modern management of zakat. Zakat management means the activity of managing zakat based on management principles, such as planning, organizing, actuating and controlling. The research describes Yayasan Ash Shahwah(YASA) in implementing these management principles. The research is a qualitative study. The data are collected through three stages: interview, observation, and documentation. The data in this study consists of three parts: primary, secondary and tertiary. The collected data are analyzed by using the theory of George R. Terry on Management. The findings show that YASA is a quite professional zakat institution. It has applied the principles of modern management. As a result, it has won the attention of people and has successfully collected more than $R p .1 .7$ billion each year.

Penelitian ini membahas tentang manajemen zakat modern. Manajemen zakat modern dimaksud adalah pengelolaan zakat dengan menggunakan dasar-dasar teori manajemen seperti planning, organizing, actuating dan controlling.Tujuan dari penelitian ini adalah untuk mendeskripsikan bagaimana Yayasan Ash Shahwah melakukan planning, organizing, actuating, dan controlling dalam menjalankan organisasi zakat. Penelitian ini adalah penelitian kualitatif. Cara pengumpulan data melalui tiga tahap yaitu wawancara, observasi, dan dokumentasi. Data-data dalam penelitian ini terdiri dari tiga bagian yakni, data primer, skunder dan tertier. Data yang terkumpul dianalisis dengan teori George $R$. Terry tentang Manajemen.Dari hasil penelitian menunjukkan bahwa YASA merupakan lembaga pengelola zakat yang cukup professional. Mereka telah menerapkan prinsip-prinsip manajemen modern sehingga kepercayaan masyarakat begitu besar dan penghimpunan dana ZIS tiap tahun tidak kurang dari Rp. 1.7 milyar.
\end{abstract}

Kata Kunci: Manajemen Zakat, Zakat Produktif

Kesenjangan penghasilan rizki dan mata pencaharian di antara umat manusia adalah hal yang tidak bisa ditolak, karena ini merupakan sunnatullah agar kehidupan ini berjalan seimbang. Untuk mengurangi kesenjangan tersebut harus ada campur tangan Allah, yaitu dengan diwajibkannya zakat dari si kaya untuk diberikan kepada si miskin bukan hanya sekedar amal tathawwu' (sunah) yang sifatnya opsional. Dengan zakat kesenjangan sosial, dapat diminimalisasikan dan rasa gotong royong serta tenggang rasa di kalangan umat Islam dapat ditumbuh kembangkan.

Menurut Yusuf al-Qardhawi, zakat merupakan ibadah ma liyah ijtima'iyyah (bersifat material dan sosial). Dengan kata lain bahwa zakat mempunyai dua dimensi yaitu dimensi material dan sosial 
yang sangat penting bagi kehidupan manusia. ${ }^{1}$ Zakat mempunyai manfaat yang sangat besar baik bagi muzakki maupun mustahiq, bagi harta maupun masyarakat secara umum. ${ }^{2}$ Hikmah disyariatkannya zakat terbagi menjadi tiga aspek yaitu aspek diniyyah, khuluqiyyah, dan ijtimaiyyah (keagamaan, akhlak, dan sosial). ${ }^{3}$

Lain lagi menurut Abdul Hamid Mahmud alBa'lybahwazakatmerupakan salah satu tambahan pemasukan (income). Hal ini akan menyebabkan adanya peningkatan pada permintaan barang pada pasar. Sedangkan pada sektor produksi, zakat akan menyebabkan bertambahnya produktifitas, sehingga perusahaan-perusahaan yang telah ada akan semakin bergerak maju, bahkan memunculkan berdirinya perusahaanperusahaan baru untuk menghadapi permintaan tersebut. ${ }^{4}$ Isnaini menjelaskan bahwa zakat mempunyai beberapa dimensi yang sangat luas yaitu dimensi agamis, moral-spiritual, finansial, ekonomis, sosial politik, yang pada akhirnya adalah untuk mencapai kemakmuran dan kesejahteraan masyarakat. ${ }^{5}$

Sementara dalam aspek pendistribusian dana zakat, sejauh ini terdapat dua pola penyaluran zakat, yaitu pola tradisional (konsumtif) dan pola penyaluran produktif (pemberdayaan ekonomi). Sekarang ini mulai tumbuh lembagalembaga amil zakat yang memberikan dananya secara produktif, di antaranya adalah yang dilakukan oleh KH. Sahal Mafudh, dengan membentuk Badan Pengembangan Masyarakat Pesantren (BPMP) yang memberikan dana zakat kepada kaum fakir miskin dengan pendekatan kebutuhan dasar. ${ }^{6}$ Begitu pula Dompet Dhuafa Republika sebagai salah satu lembaga zakat non pemerintah, sejak bulan Desember 1999 telah

${ }^{1}$ Yusuf Qardhawi, Al-Ibadah fi al-Islam, (Beirut: Muassasah al-Risalah, 1993), h. 235.

${ }^{2}$ Abdurrahman Qadir, Zakat dalam Dimensi Mahdhah dan Sosial, (Jakarta: Raja Grafindo Persada, 1998), h. 82.

${ }^{3}$ Fakhruddin membagi hikmah disyariatkannya zakat menjadi tiga aspek yaitu aspek diniyyah, khuluqiyyah, dan ijtimaiyyah. Lihat dalam Fakhruddin, Figh $\mathcal{E}$ Manajemen Zakat di Indonesia, (Malang: UIN Malang Press, 2008), h. 30.

${ }^{4}$ Abdul Hamid Mahmud al-Ba'ly, Ekonomi Zakat Sebuah Kajian Moneter dan Keuangan Syariah, (Jakarta: Raja Grafindo Persada, 2006), h. 126-127.

${ }^{5}$ Isnaini, Zakat Produktif Dalam Perspektif hukum Islam, (Yogyakarta: Pustaka Pelajar, 2008), h. 43-44.

${ }^{6}$ Sahal Mahfudh, Nuansa Figh Sosial, (Yogyakarta: LKiS, 2004), h. 119-122. mengagendakan pengembangan pemberdayaan zakat model kelompok dengan program Masyarakat Mandiri (MM). ${ }^{7}$

Selain itu Yayasan Amal Sosial Ash Shahwah Malang selanjutnya disingkat menjadi YASA Malang merupakan sebuah lembaga amil zakat (LAZ) yang menjadikan zakat dan wakaf sebagai fokus pengelolaan. Lembaga ini berdiri sejak 18 tahun yang lalu yaitu tahun 1994, dan pengurus Yayasan Ash Shahwah telah membuat akta notaris dan kelengkapan sebagai Lembaga Amil Zakat (LAZ) dengan nama Yayasan Amal Sosial Ash Shahwah (Yasa). ${ }^{8}$

Sejak berdiri pada tahun 1994 hingga kini, sudah banyak program yang dilakukan oleh YASA di bidang pendidikan: B-Gen (Beasiswa Generasi Negeri), SMA (Sekolah Mitra Andalan), CITA (Cinta Guru Kita). Di bidang pemberdayaan: Yatim Bahagia. Di bidang dakwah: MATA (Majlis Taklim Ash Shohwah), SLI (Sinergi Lembaga Islam), Qurban Membahagiakan, Rehab Masjid dan Mushalla, Da'i YASA. Di bidang Ekonomi: PANDU MANDIRI (Pinjaman Modal Usaha Mandiri), HIDUP (Hibah Dana Usaha Produktif), PADAMU (Pelatihan dan Pendampingan Manajemen Usaha), Pinjaman Ekonomi Ta'awun. Di bidang kesehatan RSY (Rumah Sehat Yasa), SUNTIK (Santunan Untuk Biaya Kesehatan), Bunda Bagia, SIGALA (Intervensi Gizi Anak dan Manusia). Di Bidang Kemanusiaan: Aksi Tanggap Bencana (ATB), STMJ (Santunan Tunai Manula dan Janda), Panti Asuhan Mitra, Bedah Rumah dan Fasilitas Umum, Layanan Ambulans Gratis, PPYD AL-IKHLAS (Pondok Pesantren Yatim dan Dhuafa al-Ikhlas). ${ }^{9}$

Dalam pengelolaan dana zakat di YASA ada permasalahan penting yang akan menjadi sorotan dalam penelitian ini. Yaitu yang berkaitan dengan manajemen pengelolaan zakat produktif. Apakah pengelolaan dana zakat produktif di YASA sudah sesuai dengan manajemen zakat modern atau belum. Dalam penelitian ini akan menggunakan teori manajemen yang digagas oleh George R. Terry dalam Dasar-

\footnotetext{
${ }^{7}$ Ibid., h. 81.

${ }^{8}$ Profil Yayasan Amal Sosial Ash Shahwah ${ }^{9}$ Ibid.
} 
dasar Manajemen ${ }^{10}$ yaitu meliputi perencanaan (planning), pengorganisasian (organizing), pelaksanaan (actuating) pengarahan dan pengawasan (controlling).

Realitas-realitas di atas mendorong peneliti untuk mencermati lebih dalam tentang obyek penelitian pada aspek pengelolaan zakat produktif, dengan menjadikan YASA Malang sebagai fokus penelitian. Menurut peneliti ada beberapa keunikan dan kekhasan yang dimiliki oleh YASA Malang. Pertama, YASA adalah lembaga amil zakat yang berkembang pesat hal ini terbukti dengan total dana masuk tiap tahun tidak kurang dari Rp. 1.7 milyar. Kedua, penyaluran dana zakat yang sangat variatif seperti program pendidikan, program yatim, program da'wah, program ekonomi, program kesehatan, program kemanusiaan, layanan ambulan gratis, pondok pesantren Yatim dan Dhuafa al-Ikhlas, sehingga manfaat keberadaan YASA dapat dirasakan para mustahiq di berbagai bidang. Terutama untuk penyaluran di bidang pendidikan menghabiskan $73 \%$ dari total penyaluran yang dilakukan YASA. ${ }^{11}$ Karena alasan-alasan tersebut, maka pengelolaan zakat produktif dipandang penting untuk dikaji lebih dalam. Titik tolak permasalahannya adalah bagaimana manajemen zakat produktif di YASA Malang dilakukan, dan bagaimana pengelolaan itu dalam perspektif manajemen zakat modern.

Tata kerja dasar manajemen zakat modern sebagaimana ditulis oleh Fakhruddin meliputi empat hal yaitu: (1) Perencanaan pengelolaan zakat, yang meliputi perencanaan strategis kelembagaan, perencanaan tujuan kelembagaan termasuk di dalamnya adalah perencanaan program seperti program ekonomi, social, pendidikan, dan dakwah. (2) Pengorganisasian pengelolaan dana zakat yang terdiri dari pimpinan, sumber daya manusia (SDM), system operasional pengelola zakat; (3) Pelaksanaan pengelolaan zakat yang meliputi: penghimpunan, pendistribusian dan pendayagunaan zakat; (4) Pengawasan dalam pengelolaan zakat, meliputi pengawasan dari dalam diri amil sendiri dan

\footnotetext{
${ }^{10}$ Yayat M. Herujito, Dasar-Dasar Manajemen, (Jakarta: Penerbit Grasindo, 2001), h. 3

${ }^{11}$ Wawancara; Andi Tricahyono, SE, Tanggal 24 Juli 2012.
}

pengawasan dari luar berupa Dewan Syariah yang dilembagakan secara structural, yang bersifat formal. ${ }^{12}$

\section{METODE PENELITIAN}

Jenis penelitian ini adalah termasuk penelitian kualitatif, karena sifat data yang akan dikumpulkan bercorak kualitatif. Secara umum penelitian kualitatif bertujuan untuk memahami dunia makna yang disimbolkan dalam perilaku kelompok masyarakat menurut perspektif masyarakat itu sendiri. ${ }^{13}$ Oleh karena itu data penelitian bersifat naturalis dengan memakai logika induktif dan pelaporannya bersifat deskriptif.

Metode deskriptif dapat diartikan sebagai prosedur pemecahan masalah yang diselidiki dengan menggambarkan/melukiskan keadaan subyek/obyek penelitian pada saat sekarang berdasarkan fakta-fakta yang tampak, atau sebagaimana adanya. ${ }^{14}$ Studi lapangan dilakukan dengan memilih YASA Malang. Lembaga ini dipilih karena memang sesuai dengan maksud penelitian yaitu untuk meneliti lembaga amil zakat yang memproduktifkan dana zakat dalam sistem distribusinya, tidak seperti lembaga amil zakat lain yang konsentrasi pendistribusiannya lebih terfokus pada pola konsumtif.

Dengan metote Field research, peneliti terjun langsung menggali data di lapangan dengan cara wawancara dan melakukan deskripsi di lapangan untuk mempelajari masalah-masalah dalam lembaga YASA Malang. ${ }^{15}$ Wawancara kepada Ketua YASA Malang, para pengurus YASA Malang, penerima dana zakat produktif YASA Malang serta pihak-pihak lain yang terkait, dimaksudkan untuk mendengar keterangan dari mereka dengan fakta-fakta, kejadian-kejadian yang mereka alami dan

\footnotetext{
${ }^{12}$ Lihat Fakhruddin, Figh \& Manajemen....., h. 268322.

${ }^{13}$ Imam Suprayogo dan Tabroni, Metode Penelitian Sosial Agama, (Bandung: Remaja Rosda Karya, 2001), h. 9

${ }^{14}$ Hadari Nawawi, Metode Penelitian Bidang Sosial, (Yogyakarta: Gajah Mada University Press, 2007), h. 67.

${ }^{15}$ Robert Bogdan \& Stevan J Taylor, Introduction to Qualitative Methods Research, A Phenomenological Approach to Social Sciences, (New York: John Willey \& Son, 1975), h. 33.
} 
mereka ketahui. ${ }^{16}$

Sedangkan pendekatan yang digunakan adalah pendekatan Manajemen zakat modern. Manajemen zakat modern dianggap tepat untuk dijadikan pisau analisis karena hakikat yang ingin diketahui dalam penelitian ini adalah bagaimana manajemen zakat modern diterapkan di YASA Malang. Dengan menggunakan teori manajemen zakat modern ini, diharapkan bisa membedah praktek penghimpunan dan pendistribusian zakat produktif di YASA Malang.

\section{Zakat Produktif}

Penggunaan kata zakat dengan berbagai derefasinya di dalam al-Qur'an terulang sebanyak 30 kali dan 27 kali di antaranya digandengkan dengan kewajiban mendirikan salat. Di samping pemakaian kata zakat dalam berbagai ayat itu, al-Qur'an juga menggunakan kata al-s\}adaqah (sedekah) dengan makna zakat, seperti dalam surat al-Taubah (9) ayat: 58, 60, dan 103. Di dalam hadith Rasulullah SAW dijumpai juga kata al-s\}adaqah yang berarti zakat. Di antaranya hadith: "Kurang dari lima wasaq $(652,8 / 653 \mathrm{~kg})$ tidak dikenai sedekah (zakat)...(HR. al-Bukhari dan Muslim) dan "Beritahulah mereka bahwa Allah mewajibkan sedekah (zakat) yang diambilkan dari harta orang-orang kaya...(HR. Bukhari, Muslim, Abu Dawud, al-Tirmidzi, al-Nasa'i, Ibn. Majah, dan Ahmad bin Hanbal). ${ }^{17}$

Kata zakat berasal dari bahasa Arab: al-zaka>h yang berarti suci, berkembang, berkah, tumbuh, bersih, dan baik. Zakat adalah salah satu rukun Islam yang bersifat ibadah dan sosial, yang kewajibannya sering digandengkan dengan kewajiban salat. Dalam Islam, zakat dibagi menjadi dua yaitu zakat mal (zakat harta) dan zakat fitri (zakat fitrah). Yusuf al-Qardawi (tokoh fikih dari Mesir) mengemukakan definisi zakat yaitu sejumlah harta tertentu yang diwajibkan

\footnotetext{
L. Adam, Method and Forms of Infestigation and Recording of Native Customary Law in The Netherlands East Indies before the War (Oxford: Oxford University Press, 1952), h. 5.

${ }^{17}$ Abdul Aziz Dahlan, editor, Ensiklopedi Hukum Islam, Jilid 6, (Jakarta: Ichtiar Baru Van Hoeve, 1996), h. 1986 .
}

Allah menyerahkannya kepada orang-orang yang berhak. Menurutnya, zakat juga bisa berarti mengeluarkan jumlah harta tertentu itu sendiri. Artinya, perbuatan mengeluarkan hak yang wajib dari harta itu pun dinamakan zakat dan bagian tertentu yang dikeluarkan dari harta itu pun dikatakan zakat. ${ }^{18}$

Kata produktif secara bahasa berasal dari bahasa Inggris " productive" yang berarti banyak menghasilkan; memberikan banyak hasil; banyak menghasilkan barang-barang berharga; yang mempunyai hasil baik. "Produktifity" berarti daya produksi. Secara umum produktif (productive) berarti banyak menghasilkan karya atau barang. Produktif juga berarti "banyak menghasilkan; memberikan banyak hasil. Pengertian produktif dalam penelitian ini lebih berkonotasi kepada kata sifat. Dalam hal ini kata yang disifati adalah kata zakat, sehingga menjadi zakat produktif yang artinya: zakat yang dalam pendistribusiannya bersifat produktif lawan dari kata konsumtif. ${ }^{19}$

Dengan demikian zakat produktif adalah model pendistribusian zakat yang dapat membuat para mustahiq menghasilkan sesuatu secara terus menerus, dengan harta zakat yang telah diterimannya. Singkatnya zakat produktif adalah harta zakat yang diberikan kepada mustahiq tidak dihabiskan atau dikosumsi tetapi dikembangkan dan digunakan untuk membantu usaha mereka, sehingga dengan usaha tersebut mustahiq dapat memenuhi kebutuhan hidup secara terus menerus. ${ }^{20}$

\section{Manajemen Pengelolaan Zakat}

Manajemen merupakan kata serapan dari bahasa Inggris, "management" yang berakar kata "manage" yang berarti "control" kontrol dan "succeed" sukses. Dari devinisi tersebut bisa disimpulkan bahwa inti dari manajemen adalah pengendalian hingga mencapai sukses yang diinginkan. ${ }^{21}$ George R. Terry dalam Dasar-dasar Manajemen mendevinisikan manajemen adalah suatu perencanaan (planning), pengorganisasian

\footnotetext{
${ }^{18}$ Ibid.

${ }^{19}$ Isnaini, Zakat Produktif Dalam Perspektif Hukum Islam, (Yogyakarta: Pustaka Pelajar, 2008), h. 63.

${ }^{20}$ Ibid., h. 64.

${ }^{21}$ Sudirman, Zakat Dalam Pusaran Arus Modernitas, (Malang: UIN Malang Press, 2007), h. 71
} 
(organizing), pelaksanaan (actuating) pengarahan dan pengawasan (controlling). ${ }^{22}$

Dalam pengelolaan zakat, sangat erat kaitannya dengan sistem manajemen yang dipakai dalam sebuah aksi pengelolaannya. Setidaknya secara garis besar ada dua pola manajemen dalam pengelolaan zakat, yaitu manajemen tradisional dan manajemen modern. Eri Sudewo dalam memaparkan ciri pengelolaan tradisional ${ }^{23}$ memberikan 15 ciri, namun di sini hanya diambil beberapa poin yang dianggap sangat vital yaitu: (a) Anggap Sepele. Zakat merupakan bantuan, karena bantuan maka bekerja di lembaga zakat merupakan pekerjaan social semata. Karena sifatnya sosial maka tidak perlu diseriusi, dan bisa dilakukan sambil lalu. (b) Pekerjaan Sampingan. Pekerjaan sosial adalah pekerjaan kedermawanan hati seseorang. Dengan demikian rasa social ini akan sangat tergantung dengan suasana hati. Rasa social akan bangkit di saat hati sedang bahagia. Akan tetapi di saat seseorang dilanda masalah dan banyak menemui kegagalan, kondisi jiwapun labil. Dengan kondidi demikian format berpikir yang tumbuh menempatkan pekerjaan social hanyalah sampingan dan aksidental. (c) Tanpa Manajemen. Pengelolaan zakat sering kali berjalan apa adanya tanpa manajemen yang jelas. Manajemen dalam arti sesungguhnya tidak mereka kenal. Pembagian tugas dan struktur organisasi hanya formalitas. Struktur disesuaikan dengan keinginan pengelola atau pendiri tanpa adanya pertimbangan kebutuhan riil organisasi. Pembagian tugas juga belum sepenuhnya dipahami oleh anggota organisasi. (d) Tanpa Seleksi Sumber Daya Manusia. Di antara kebiasaan lembaga nirlaba di Indonesia termasuk lembaga pengelola ZIS adalah tidak serius dalam menyeleksi SDM pengelola. Sangat jarang ada system rekrutmen yang pasti, apalagi fit and proper test yang dirasa terlalu berlebihan. (e) Ikhlas Tanpa Imbalan. Manajemen ikhlas beramal masih menjadi pola bekerja di 22 Yayat M. Herujito, Dasar-Dasar Manajemen, (Jakarta: Pt. Grasindo, 2001), h. 3

${ }^{23}$ Eri Sudewo, Manajemen Zakat Tinggalkan 15 Tradisi Terapkan 4 Prinsip Dasar, (Ciputat: Institut Manajemen Zakat, 2004), h. 11. Lihat juga Sudirman, Zakat Dalam Pusaran Arus Modernitas, (Malang: UIN Malang Press, 2007), h. 72. yayasan sosial dan panti. Ikhlas beramal berarti pengabdian yang tak perlu mendapatkan imbalan, lebih-lebih menuntut upah yang layak. (f) Kreatifitas Rendah. Pengelolaan dengan model tradisional cenderung pasif, kurang kreatif, dan tidak inovatif. Para pelaksana lebih sering menikmati keadaan dan enggan untuk melakukan terobosan-terobosan baru. (g) Tidak ada Monitoring dan Evaluasi. Salah satu dampak dari lemahnya kreativitas adalah tidak adanya sistem monitoring dan evaluasi. Jalanya organisasi masih sangat tergantung kepada pimpinan, yang menjadi kata kunci dalam kebanyakan organisasi nirlaba. Oranisasi yang hanya menggantungkan kepada pimpinan menyebabkan lemahnya system pengawasan dan evaluasi. Dengan tidak adanya system monitoring dan evaluasi, sebuah organisasi akan sulit berbenah dan berkembang. (h) Tidak Terbiasa Disiplin. Salah satu budaya bangsa Indonesia yang negativ adalah tidak terbiasa disiplin. Istilah jam karet sudah menjadi tradisi yang turun temurun, dan anehnya hal ini seakan dianggap wajar dan sah-sah saja. ${ }^{24}$

Dalam mengelola lembaga zakat agar bisa berkembang dan maju pesat, kita harus menerapkan manajemen modern. Manajemen sederhana yang bisa kita ambil seperti yang digagas oleh James Stoner, yaitu: proses perencanaan (planning), pengorganisasian (organizing), pengarahan (actuating), dan pengawasan (controlling). Eri Sudewo telah merangkum keempat aktifitas tersebut dalam bukunya Manajemen Zakat, yaitu: perencanaan, pengorganisasian, pelaksanaan dan pengarahan, serta pengawasan.

Perencanaan merupakan suatu proses untuk membuat rancangan-rancangan agenda kegiatan yang akan dilakukan oleh sebuah organisasi. Perencanaan terkait dengan berbagai hal di antaranya: terkait dengan waktu dan strategi. Pertama, perencanaan waktu, sering dibagi dalam tiga tahap, yaitu perencanaan jangka pendek, menengah, dan jangka penjang. Yang dimaksud perencanaan jangka pendek adalah

${ }^{24}$ Eri Sudewo, Manajemen Zakat Tinggalkan 15 Tradisi Terapkan 4 Prinsip Dasar, (Ciputat: Institut Manajemen Zakat, 2004), h. 11-20. 
perencanaan yang dibatasi dengan waktu satu tahun, sedangkan perencanaan jangka menengah biasanya akan dilakukan dalam kisaran waktu antara satu sampai tiga tahun. Untuk perencanaan jangka panjang, waktu yang dibutuhkan adalah tiga sampai lima tahun. Kisaran waktu tersebut bisa dirubah sesuai dengan situasi kondisi dan kebutuhan organisasi.

Kedua, perencanaan strategis, adalah perencanaan yang digunakan untuk menjaga fleksibilitas rencana jangka panjang akibat berubahnya situasi dan kondisi. Rencana strategis ini bertujuan untuk menjaga eksistensi organisasi sehingga tetap bertahan. Perbedaan dengan perencanaan waktu adalah bahwa perencanaan yang pertama ini menekankan pada harmonisnya organisasi dalam beradaptasi, sedangkan perencanaan strategis justru dibuat untuk meredam gejolak yang dapat menggincang harmoni tersebut. Beberapa factor yang perlu diperhatikan dalam perencanaan strategis, di antaranya adalah rencana yang memiliki manfaat besar, sangat dibutuhkan, bersifat masa dan memiliki efek ganda. Yang tidak kalah penting dalam perencanaan strategis adalah berani untuk bertindak. ${ }^{25}$

Pengorganisasian di sini adalah cara yang ditempuh oleh lembaga untuk mengatur kinerja lembaga termasuk anggotannya. Pengorganisasian tidak bisa lepas dari koordinasi, yang sering didefinisikan sebagai upaya penyatuan sikap dan langkah dalam organisasi untuk mencapai suatu tujuan. Dalam organisasi terkumpul orang-orang yang beragam latar belakang dan kepentingan. Termasuk dalam lembaga pengelola zakat. Idealnya ketika seseorang telah memutuskan untuk berkecimpung dalam pengelolaan zakat, maka segala ego baik yang bersifat individu maupun golongan harus di buang jauh-jauh. Segala sikap yang menyimpang dari visi misi organisasi harus diluruskan.

Pelaksanaan dalam sebuah manajemen adalah aktualisasi perencanaan yang dibuat oleh organisasi. Sedangkan pengarahan adalah proses penjagaan agar pelaksanaan program kegitan dapat berjalan sesuai dengan rencana.

\footnotetext{
25 Ibid., h. 92-93.
}

Dalam pelaksanaan ada beberapa komponen yang sangat diperelukan, diantaranya adalah motivasi, komunikasi, dan kepemimpinan.

Pengawasanadalah prosesuntukmenganjurkan aktivitas positif dan mencegah perbuatan yang menyalahi aturan. Pengawasan berfungsi sebagai pengawal agar tujuan dalam organisasi dapat tercapai. Pengawasan yang paling efektif adalah pengawasan terhadap diri sendiri. Akan tetapi jika pengawasan individu tidak berjalan maka perlu diadakan pengawasan eksternal yang melibatkan orang lain atau bahkan lembaga independen. Pengawasan dalam lembaga zakat mempunyai dua substansi. Pertama, secara fungsional, pengawasan terhadap amil telah menyatu dalam diri amil. Kedua, secara formal lembaga zakat memiliki Dewan Shariah yang secara struktural berada di bawah ketua lembaga zakat. Dewan shariah yang terdiri dari pakar di bidangnya ini bertugas untuk mengesahkan mengontrol atau menghentikan setiap program yang dibuat lembaga zakat. ${ }^{26}$

\section{Sistem Penghimpunan Zakat}

Pengumpulan zakat dilakukan oleh lembaga amil zakat dengan cara menerima langsung atau mengambil dari muzakki atas dasar pemberitahuan muzakki. Lembaga amil zakat dapat bekerja sama dengan bank dengan cara membuka rekening kemudian rekening tersebut disosialisasikan kepada muzakki, kemudian muzakki langsung membayar ke bank dimaksud. Lembaga amil zakat dapat menerima harta selain zakat seperti infaq, shadaqah, hibah, wasiat, waris dan kafarat.

Setidaknya ada tiga strategi pengumpulan zakat yang bisa diterapkan oleh instansi pengelola zakat, yaitu: (a) Pembentukan unit pengumpulan zakat. Setiap badan amil zakat dapat membuka unit pengumpul zakat (UPZ) di berbagai tempat sesuai dengan tingkatannya, baik nasional, provinsi dan seterusnya; (b) Pembukaan counter penerimaan zakat. Pembukaan counter atau loket di kantor atau lembaga secretariat lembaga yang bersangkutan. Counter harus dibuat representative layaknya loket lembaga keuangan professional yang

\footnotetext{
${ }^{26}$ Ibid., h. 148.
} 
dilengkapi ruang tunggu, alat tulis, penghitung seperlunya, brankas, ditunggu dan dilayani oleh tenaga-tenaga professional; dan (c) Pembukaan rekening bank. Dalam membuka rekening bank hendaknya dipisah antara satu rekening dengan yang lainnya, semisal rekening zakat, infak, shadaqah, dan wakaf. Sehingga memudahkan bagi muzakki kemana dana tersebut harus disetor, dan juga bagi pengelola, untuk mendistribusikannya. ${ }^{27}$

\section{Pendistribusian dan Pendayagunaan Zakat}

Salah satu fungsi zakat adalah fungsi sosial, yaitu sarana bersosialisasi antara orang kaya dan orang miskin. Agar dana zakat yang disalurkan dapat berdaya guna dan berhasil guna, maka dalam pemanfaatannya harus selektif. Dalam distribusi dana zakat, setidaknya ada dua model distribusi yaitu konsumtif dan produktif. Dari kedua model tersebut kemudian masing masing terbagi menjadi dua kategori yaitu konsumtif tradisional dan konsumtif kreatif, serta produktif konvensional dan produktif kreatif.

Penyaluran secara konsumtif tradisional adalah zakat dibagikan kepada mustahiq secara langsung untuk konsumsi sehari-hari, seperti pembagian zakat mal ataupun zakat fitrah kepada mustahiq yang sangat membutuhkan karena ketiadaan pangan atau karena musibah. Program ini merupakan program jangka pendek dalam mengatasi permasalahan umat. Sedangkan yang dimaksud pendistribusian secara konsumtif kreatif adalah dana zakat dirupakan dalam bentuk barang konsumtif dan digunakan untuk membantu orang miskin dalam mengatasi permasalahan social ekonomi yang dihadapinya. Bantuan tersebut seperti alat-alat sekolah dan beasiswa untuk pelajar, bantuan sarana ibadah seperti sarung dan mukena, bantuan alat pertanian seperti cangkul untuk petani, gerobak jualan untuk pedagang dan lain-lain.

Pendistribusian zakat secara produktif konvensional adalah dana zakat yang diberikan

\footnotetext{
${ }^{27}$ Departemen Agama, Manajemen Pengelolaan Zakat, (Jakarta: Direktorat Pengembangan Zakat dan Wakaf, 2005), h. 33.
}

dalam bentuk barang-barang produktif, yang dengan pemberian tersebut mustahiq bisa menciptakan lapangan pekerjaan sendiri, seperti pemberian bantuan ternak kambing, sapi perah atau untuk membajak sawah, alat pertukangan, mesin jahit, dan sebagainya. Sedangkan pendistribusian zakat secara produktif kreatif adalah zakat diberikan dalam bentuk pemberian modal bergulir, baik untuk modal proyek social, seperti membangun sekolah, sarana kesehatan atau tempat ibadah, maupun sebagai modal usaha bagi pengembangan usaha pedagang kecil..$^{28}$

\section{HASIL DAN PEMBAHASAN}

\section{Sejarah Yayasan Amal Sosial Ash Shahwah (YASA)}

Yayasan Amal Sosial Ash Shahwah (YASA) adalah organisasi nirlaba yang bertujuan untuk memberdayakan masyarakat dhuafa serta mustahik zakat lainnya, berbasis pendidikan, dakwah, kesehatan, ekonomi dan social kemanusiaan, dengan memanfaatkan seluruh potensi kaum muslimin terutama potensi pendanaan melalui dana zakat, infak, sedekah dan wakaf.

Keberadaan YASA dimulai dengan nama Yayasan Ash Shahwah yang berdiri sejak tahun 1994 dan bergerak pada beberapa bidang, yaitu bidang pendidikan, pelayanan dakwah, Biro Baitul Mal (BBM) serta pusat dokumentasi dan informasi Islam. Seiring berjalannya waktu dan semakin banyaknya masyarakat yang menaruh kepercayaan, untuk mengokohkan aktifitasnya, sejak 12 Rabiul Awwal 1421 H/ 25 Juli 2000 M, pengurus Yayasan Ash Shahwah telah membuat akta notaris dan kelengkapan sebagai Lembaga Amil Zakat (LAZ) dengan nama Yayasan Amal Sosial Ash Shahwah (YASA). Hingga sekarang YASA tetap eksis untuk mengabdi dalam pemberdayaan masyarakat dan berpertisipasi aktif guna mengurai kemiskinan yang membelenggu sebagian kaum muslimin. ${ }^{29}$

\footnotetext{
${ }^{28} \mathrm{Ibid} .$, h. 35.

${ }^{29}$ Buku Profil YASA
} 


\section{Manajemen Pengelolaan Zakat Produktif di YASA}

Perencanaan merupakan suatu proses untuk membuat rancangan-rancangan agenda kegiatan yang akan dilakukan oleh sebuah organisasi. Perencanaan terkait dengan berbagai hal di antaranya waktu dan strategi. Pertama, perencanaan waktu, sering dibagi dalam tiga tahap, yaitu perencanaan jangka pendek, menengah, dan jangka penjang. Yang dimaksud perencanaan jangka pendek adalah perencanaan yang dibatasi dengan waktu satu tahun, sedangkan perencanaan jangka menengah biasanya akan dilakukan dalam kisaran waktu antara satu sampai tiga tahun. Untuk perencanaan jangka panjang, waktu yang dibutuhkan adalah tiga sampai lima tahun. Kedua, perencanaan strategis, adalah perencanaan yang digunakan untuk menjaga fleksibilitas rencana jangka panjang akibat berubahnya situasi dan kondisi. Rencana strategis ini bertujuan untuk menjaga eksistensi organisasi sehingga tetap bertahan..$^{30}$

\section{Perencanaan}

Dari Yayasan Ash Shahwah (YASA) Malang, yang menjadi focus penelitian ini sesungguhnya adalah YASA yang telah membuat perencanaan dengan baik. Yaitu dengan membuat rancangan program yang akan mereka lakukan pada waktu tertentu. Akan tetapi model perencanaan di YASA cenderung menggunakan perencanaan jangka pendek, yang mereka sebut dengan range kegiatan tahun 2012, tidak ada perencanaan jangka menengah maupun jangka panjang yang tertulis. Perencanaan jangka menengah YASA adalah ingin menyantuni 1000 yatim dan dhuafa' sedangkan rencana jangka panjang adalah mendirikan sekolah favorit yang diperuntukkan bagi yatim dan dhuafa' yang keduanya merupakan angan-angan Direktur YASA. Untuk mengetahui program kerja (planning) YASA, dipaparkan program kerja jangka pendek sebagai berikut:

\footnotetext{
30 $\quad$ Eri Sudewo, Manajemen Zakat...h. 92-93.
}

Tabel 1

Program Kerja

\begin{tabular}{llll}
\hline No & $\begin{array}{c}\text { Perbaikan } \\
\text { Administrasi }\end{array}$ & \multicolumn{1}{c}{ Pelayanan Mustahiq } & \multicolumn{1}{c}{$\begin{array}{c}\text { Pelayanan } \\
\text { Muzakki }\end{array}$} \\
\hline $\begin{array}{l}\text { Pengurusan } \\
\text { Legalitas } \\
\text { Hukum YASA }\end{array}$ & Pemberian Beasiswa & $\begin{array}{l}\text { Layanan Individual } \\
\text { Donatur }\end{array}$ \\
\hline 2. & $\begin{array}{l}\text { Majalah Ash } \\
\text { Shahwah }\end{array}$ & Pembinaan Rutin Anak Asuh & $\begin{array}{l}\text { Layanan Mudah } \\
\text { Berzakat }\end{array}$ \\
\hline 3. & Website YASA & $\begin{array}{l}\text { Majelis Korwilda dan Pembinaan } \\
\text { Majelis Taklim Ash Shahwah (MATA) }\end{array}$ \\
\hline 4. & Jambore Anak Sholeh & \\
\hline 5. & $\begin{array}{l}\text { Pelatihan Skill Terapan AA dan Pemuda } \\
\text { Pengangguran }\end{array}$ \\
\hline 6. & Hadiah Naik Kelas & \\
\hline 7. & Siap Jadi Sarjana (Si Jana) \\
\hline 8. & Spectra (Special Experience In \\
\hline 9. & Ramadhan) \\
\hline
\end{tabular}




\begin{tabular}{ll}
\hline 10. & Layanan Dakwah Anak Asuh \\
\hline 11. & Pelatihan Guru Hebat \\
\hline 12. & Training Manajemen Sekolah Modern \\
\hline 13. & Penyaluran Subsidi Kafalah CITA \\
\hline 14. & $\begin{array}{l}\text { Pondok Pesantren Yatim dan Dhuafa' } \\
\text { (PPYD) Al-Ikhlas }\end{array}$ \\
\hline 15. & Pengajian Rutin YASA-IKADI \\
\hline 16. & Semarak Ramadhan \\
\hline 17. & Semarak Idhul Adha \\
\hline 18. & Layanan Kajian Islam Mustahiq \\
\hline 20. & Santunan Tunai Manula dan Janda \\
\hline 21. & Bantuan Gharim \\
\hline 22. & Bantuan Fakir Miskin \\
\hline 23. & Bantuan Muallaf \\
\hline 24. & Bantuan Ibn Sabil \\
\hline 25. & Aksi Tanggap Bencana \\
\hline 26. & Bantuan Kesehatan dan Bundsa Bahagia \\
\hline 27. & Khitan Massal Gratis \\
\hline 29. & Layanan Ambulance \\
\hline 30. & Rumah Sehat YASA \\
\hline & Hibah Modal Usaha \\
\hline
\end{tabular}

Dari tabel di atas tampak bahwa konsentrasi program YASA pada tahun 2012 lebih terfokus pada pelayanan mustahiq. Hal ini dikarenakan secara administrasi, YASA sudah bisa dikatakan tertib administrasi karena system keuangan sudah terpilah-pilah dengan baik, laporan sirkulasi keuangan juga sudah terkendali. Begitu juga dengan administrasi surat menyurat.31Namun demikian bukan berarti perbaikan administrasi di YASA tidak dilakukan. Pada tahun ini, YASA merencanakan untuk mengurus legalitas hukum. Dengan adanya legalitas hukum ini diharapkan pengelolaan ZIS dan wakaf di YASA sah di mata hukum.

YASA juga akan membuat Website yang beberapa waktu lalu sempat tertunda karena orang yang diserahi tidak bertanggung jawab. Dengan adanya website, diharapkan semua kegiatan dan berita YASA bisa diupload di internet. Website merupakan media untuk

\footnotetext{
${ }^{31}$ Nina Adriani, wawancara, 7 Agustus 2012.
}

sosialisasi dan promosi YASA serta untuk laporan pertanggungjawaban kepada para muzakki. Disamping itu, untuk mendukung sosialisasi, YASA juga telah menerbitkan majalah Ash Shahwah yang sebelumnya terbit dua bulan sekali, sekarang meningkat menjadi satu bulan sekali, bakan dari segi isinya juga mengalami penambahan.

Pada tahun 2012, pelayanan pada mustahiq pada tampak mendominasi. Hal ini dapat dilihat dari tabel di atas dengan banyaknya program untuk mustahiq. Dana yang tersalur pada program pendidikan dan anak yatim saja mencapai $73 \%$ dari keseluruhan program yang ada.32 Kebijakan tersebut sesuai dengan motto Ash Shahwah, yaitu satu hati sejuta peduli. Dengan kepedulian kepada mustahiq, berarti bisa memberikan kontribusi dalam

\footnotetext{
${ }^{32}$ Majalah Ash Shahwah edisi 66/Tahun 12/JuliAgustus 2012, Laporan Pendistribusian ZISWAF
} 
membangun umat yang lebih baik..$^{33}$ Sedangkan untuk pelayanan terhadap muzakki, YASA mencanangkan dua program yaitu layanan individual donatur dan layanan mudah berzakat. Layanan individual donator berupa penjemputan zakat ke rumah-rumah donator, sedangkan layanan mudah berzakat adalah membuka rekening pada beberapa bank seperti BCA, BNI Syariah, Bank Muamalat, dan Bank Syariah Mandiri.

Dari aspek pengorganisasian, YASA terlihat sudah menerapkan pengelolaan organisasi yang relatif baik. Data tersebut dapat dilihat melalui hubungan koordinasi antara staf dengan pucuk pimpinan yang terdapat pada skema struktur organisasi sebagai berikut:
Model kepemimpinan di YASA cenderung mengacu pada model kepemimpinan demokratis. Hal ini terlihat ketika Direktur ingin mengajukan program, maka yang bersangkutan harus mengusulkan dulu pada forum rapat mingguan. Jika usulan itu disetujui oleh forum, maka selanjutnya dibawa ke forum rapat besar yang melibatkan semua pengurus dan penasehat. Disamping itu, system koordinasi antara atasan dan bawahan terlihat berjalan normal tanpa adanya sekat. Mereka sewaktu-waktu dapat berkoordinasi satu sama lain jika memang dibutuhkan karena mereka berada dalam satu kantor kecuali koordinator program Pesantren Yatim dan Dhuafa' yang berada di Singosari. Sedangkan petugas YASA sebanyak 13 orang, mereka semua aktif pada pos masing-masing

Tabel 2

Struktur Organisasi

\begin{tabular}{|c|c|c|c|}
\hline No & Jumlah Pegawai & Pimpinan Tertinggi & Struktur di Bawah Pimpinan \\
\hline 1. & 13 Orang & Direktur & $\begin{array}{l}\text { 2Manajer, } 7 \text { staf dan } 3 \text { Koordinator program: } \\
\text { Manajer Keuangan dan Manajer Fundrising, } \\
1 \text { staf Administrasi yang membantu kerja } \\
\text { Manajer Keuangan dan } 6 \text { staf Fundrising } \\
\text { yang terbagi menjadi dua kelompok: } \\
4 \text { Konsultan ZIFAS, dan } 2 \text { Layanan } \\
\text { Donatur Koordinator Pendidikan Sosial } \\
\text { Kemasyarakatan, Koordinator Kesehatan } \\
\text { dan Koordinator Pesantren Yatim dan } \\
\text { Duafa' (PPYD) al-Ikhlas. }\end{array}$ \\
\hline
\end{tabular}

${ }^{33}$ Andi Tricahyono, dalam Majalah Ash Shahwah; Jendela hati, h. 2 sehingga lembaga ini sukses mengelola dana ZIS dan Wakaf yang jumlahnya sekitar 1.7 milyar per tahun.

\section{Pelaksanaan}

Pelaksanaan dalam sebuah manajemen adalah aktualisasi perencanaan yang dibuat oleh organisasi. Sedangkan pengarahan adalah proses penjagaan agar pelaksanaan program kegitan dapat berjalan sesuai dengan rencana. ${ }^{34}$ Dalam penelitian ini ditemukan bahwa YASA telah melaksanakan program-program yang telah direncanakan dengan baik.

\footnotetext{
${ }^{34}$ Eri Sudewo, Manajemen Zakat...h. 133.
} 
Tabel 3

Pelaksanaan

\begin{tabular}{|c|c|c|c|c|c|}
\hline No & Penghimpunan & Asnaf & $\begin{array}{l}\text { Jumlah } \\
\text { Donatur }\end{array}$ & Penyaluran & Aksidental \\
\hline 1. & $\begin{array}{l}\text { Donatur dari berbagai } \\
\text { kalangan seperti } \\
\text { Dokter, karyawan } \\
\text { swasta, Pegawai } \\
\text { Negeri Sipil, jumlah } \\
\text { penghimpunan pada } \\
\text { tahun } 2011 \text { mencapai } \\
1.7 \text { milyar }\end{array}$ & $\begin{array}{l}\text { F a k i r, } \\
\text { miskin, amil, } \\
\text { sabilillah, } \\
\text { g h a r i m, } \\
\text { muallaf, ibn } \\
\text { sabil }\end{array}$ & $\begin{array}{l}\mathrm{T} \text { i d a k } \\
\text { terdeteksi }\end{array}$ & $\begin{array}{l}\text { Program beasiswa } \\
\text { generasi negeri, } \\
\text { cinta guru kita, } \\
\text { pemberd ay a an } \\
\text { ekonomi, program } \\
\text { keagamaan/dakwah, } \\
\text { program kesehatan } \\
\text { dan kemanusiaan, } \\
\text { program yatim, } \\
\text { bantuan fakir miskin, } \\
\text { fi sabilillah }\end{array}$ & $\begin{array}{l}\text { Aksi tanggap } \\
\text { bencana }\end{array}$ \\
\hline
\end{tabular}

Dari tabel di atas Nampak jelas bahwa donator YASA berasal dari berbagai latar belakang yang berbeda-beda, mulai Dokter, Karyawan swasta, Pegawai Negeri Sipil, sehingga dana yang terkumpul pada tahun 2011 mencapai 1.7 milyar. Hal ini tentu tidak lepas dari kegigihan manajer fundrising dan para relawan penjemput zakat serta layanan yang diberikan YASA kepada donator seperti membuka rekening di beberapa bank yang ada di Malang.

Untuk penghimpunan dana, di bawah struktur Manajer Fundrising ada Konsultan zakat, infak, shodaqaoh (ZIFAS) atau yang disingkat dengan KZ. Tugas KZ ini adalah mencari donator baru, target mereka untuk satu orang $\mathrm{KZ}$ adalah 1 juta rupiah perbulan. YASA mempunyai $4 \mathrm{KZ}$. Target utama KZ adalah orang-orang terdekat mereka, instansi pemerintah dengan cara silaturrahim. Silaturrahim ini dilakukan minimal kepada 3 orang per hari.

Selanjutnya ada tim lain yang bernama tim Layanan Donatur yang disingkat dengan LD. Yasa mempunyai 2 orang LD yang bertugas menjemput dana dari para donator lama yang telah didapat oleh KZ. LD ini datang langsung ke donator melalui koordinator donatur. Dana dari LD disetor langsung ke Manajer Keuangan. Untuk penghimpunan pada bulan Ramadhan tahun 2012 ini terkumpul dana sebesar 1.2 milyar. Dan jumlah keseluruhan terhitung dari bulan januari sampai dengan agustus adalah sekitar 1.76 milyar rupiah. ${ }^{35}$

Adapun dalam masalah penyeluran YASA menyalurkan dana ZIS dan wakaf kepada 7 golongan yaitu: fakir, miskin, amil, sabilillah, gharim, muallaf, ibn sabil. Ketujuh golongan tersebut diadaptasikan namanya dengan program-program yang dicanangkan oleh YASA seperti Beasiswa generasi negeri, cinta guru kita, pemberdayaan ekonomi, program keagamaan/dakwah, program kesehatan dan kemanusiaan, program yatim bantuan tunai fakir miskin, dan sabilillah. Namun dari 7 golongan tersebut golongan sabilillah menjadi focus perhatian YASA dengan memberikan beasiswa kepada para pelajar mulai dari SD sampai perguruan tinggi yang terbagi menjadi dua kategori yaitu pelajar miskin dan pelajar yatim. Jumlah pelajar yatim yang disantuni YASA saat ini sebanyak 231 anak, sedangkan untuk dhuafa' sebanyak 545, jadi jumlah keseluruhan anak asuh YASA adalah 776 anak. Untuk penyaluran di bidang beasiswa ini mencapai $73 \%$ dari seluruh penyaluran yang dilakukan oleh YASA. ${ }^{36}$

\footnotetext{
${ }^{35}$ Farhan Jamil, Wawancara, 11-Oktober 2012.

${ }^{36}$ Majalah Ash Shahwah edisi 66/Tahun 12/JuliAgustus 2012, h. 56.
} 


\section{Pengawasan}

Pengawasan adalah proses untuk menganjurkan aktivitas positif dan mencegah perbuatan yang menyalahi aturan. Pengawasan berfungsi sebagai pengawal agar tujuan dalam organisasi dapat tercapai. Pengawasan yang paling efektif adalah pengawasan terhadap diri sendiri. Akan tetapi jika pengawasan individu tidak berjalan maka perlu diadakan pengawasan eksternal yang melibatkan orang lain atau bahkan lembaga independen. ${ }^{37} \mathrm{Di}$ bawah ini dipaparkan tabel tentang system pengawasan yang ada di YASA

${ }^{37}$ Eri Sudewo, Manajemen Zakat.... h. 148.

Tabel 4

Pengawasan

\begin{tabular}{|c|c|c|c|}
\hline No & Sistem & Media Massa & Tim Pengawas \\
\hline \multirow[t]{4}{*}{1.} & $\begin{array}{l}\text { a.Individual/Kajian Tafsir Ibn } \\
\text { Katsir \& Fiqih Sunnah setiap } \\
\text { hari }\end{array}$ & Majalah Ash Shahwah & $\begin{array}{l}\text { Dewan Pembina, } \\
\text { Dewan Penasehat, } \\
\text { dan Pengawas }\end{array}$ \\
\hline & $\begin{array}{l}\text { b. Koordinasi Mingguan pengurus } \\
\text { harian }\end{array}$ & & \\
\hline & $\begin{array}{l}\text { c.Koordinasi Bulanan dengan } \\
\text { dewan penasehat dan dewan } \\
\text { pembina }\end{array}$ & & \\
\hline & d.Buletin & & \\
\hline
\end{tabular}

Untuk pengawasan internal, YASA selalu mengadakan pengawasan yang melibatkan semua pengurus harian melalui koordinasi mingguan dan koordinasi bulanan dengan para dewan penasehat dan dewan pembina. Melalui koordinasi tersebut, diharapkan jika ada kesalahan pelaporan keuangan atau kesalahan prosedural dapat segera diatasi, sehingga kepercayaan para muzakki terhadap lembaga selalu terpelihara. Laporan keuangan yang dikelola YASA telah dipublikasikan oleh majalah Ash Shahwah yang terbit setiap dua bulan sekali. Di bulletin ini terdapat laporan pendistribusian ZISWAF. Misalnya pada edisi bulan September 2012, dana yang disalurkan YASA pada bulan Juli dan Agustus sebesar Rp. 610, 571, 957, yang meliputi program pendidikan, program keagamaan/dakwah, program kesehatan, program yatim, program pemberdayaan ekonomi. Para donatur, dewan penasehat dan dewan pembina serta pengawas, selalu diberi majalah sebagai bentuk laporan pertanggungjawaban YASA kepada mereka, serta merupakan bentuk audit eksternal walaupun belum maksimal.Dari paparan di atas, inti dari manajemen YASA dapat disimpulkan secara singkat pada tabel berikut:

Tabel 5

Unsur Manajemen

\begin{tabular}{cclcc}
\hline No & Perencanaan & \multicolumn{1}{c}{ Organisasi } & Pelaksanaan & Pengawasan \\
\hline 1. & Banyak program untuk & Staf banyak dan & Danaterkumpul & Audit internal \\
& mustahiq & bekerja semua & banyak dan dan eksternal \\
& bahkan sampai tersalurkan walau eksternal \\
& double job & dengan baik, b e $1 \mathrm{u} \mathrm{m}$ \\
& & nama donator maksimal \\
& & tidak diekspos \\
\hline
\end{tabular}


Singkatnya lembaga social YASA telah melakukan unsur-unsur manajemen dengan baik, walaupun masih ada sedikit kekurangan semisal kurangnya program untuk muzakki, beberapa staf yang harus menghadle beberapa pekerjaan sekaligus, walaupun sebenarnya tidak sampai mengganggu jalannya organisasi, seandainya namanama donator baik yang tetap maupun yang tidak tetap bisa diekspos tentu ini akan lebih baik dalam rangka transparansi lembaga. Dan terakhir jika saja ada audit eksternal yang independen maka hal ini akan lebih baik dari pada sekedar majalah yang dikirimkan kepada para donator, pengawas, dewan penasehat, dewan pembina setiap dua bulan sekali.

\section{KESIMPULAN}

Dalam mengelola ZISWAF, YASA telah menerapkan teori George R. Terry, terkait empat unsur penting dalam manajemen yaitu: perencanaan (planning), pengorganisasian (organizing), pelaksanaan (actuating), dan pengawasan (controlling). Meskipun unsur-

\section{Daftar Pustaka}

Adam, L. Method and Forms of Infestigation and Recording of Native Customary Law in The Netherlands East Indies before the War, Oxford: Oxford University Press, 1952.

Al-Qardhawi,Yusuf. Al-Ibadah fial-Islam, Beirut: Muassasah al-Risalah, 1993.

Al-Ba'ly, Abdul Hamid Mahmud. Ekonomi Zakat Sebuah Kajian Moneter dan Keuangan Syariah, Jakarta: Pt. Raja Grafindo Persada, 2006.

Bogdan, Robert \& Taylor, Stevan J Introduction to Qualitative Methods Research, A Phenomenological Approach to Social Sciences, New York: John Willey \& Son, 1975.

Dahlan, Abdul Aziz. editor, Ensiklopedi Hukum Islam, Jilid 6, Jakarta: Ichtiar Baru Van Hoeve, 1996.

Fakhruddin. Fiqh E Manajemen Zakat di Indonesia, Malang: UIN Malang Press, 2008.

Herujito, Yayat M. Dasar-Dasar Manajemen, unsur manajemen telah diterapkan, namun pengelolaannya masih perlu ditingkatkan agar mendapat kepercayaan lebih dari masyarakat. Dari data yang diperoleh, pada tahun 2011 YASA telah berhasil menghimpun dana dari muzakki sekitar Rp. 1.7 milyar. Sedangkan dari rentang waktu Januari-Agustus 2012, dana yang berhasil dihimpun sebesar Rp. 1.76 milyar. Dana yang terlah terhimpun, kemudian oleh YASA disalurkan kepada 7 golongan yaitu: fakir, miskin, amil, sabilillah, gharim, muallaf, ibn sabil. Ketujuh golongan tersebut diadaptasikan namanya melalui programprogram seperti beasiswa generasi negeri, cinta guru kita, pemberdayaan ekonomi, program keagamaan/dakwah, program kesehatan dan kemanusiaan, program yatim bantuan tunai fakir miskin, dan lain-lain. Dari berbagai program penyaluran dana tersebut, golongan sabilillah menjadi focus perhatian YASA yang diwujudkan dalam bentuk beasiswa pelajar mulai dari SD sampai perguruan tinggi yang masuk kategori yaitu miskin dan yatim. Pelaporan pengelolaan dana oleh YASA telah dilakukan secara transparan meskipun pengawasan masih dilakukan secara internal.

Jakarta: Pt. Grasindo, 2001.

Isnaini. Zakat Produktif Dalam Perspektifhukum Islam, Yogyakarta: Pustaka Pelajar, 2008.

Mahfudh, Sahal. Nuansa Figh Sosial,Cet. Ke-4, Yogyakarta: LKiS, 2004.

Nawawi, Hadari. Metode Penelitian Bidang Sosial, Yogyakarta: Gajah Mada University Press, 2007.

Profil Yayasan Amal Sosial Ash Shahwah.

Qadir, Abdurrahman. Zakat dalam Dimensi Mahdhah dan Sosial, Jakarta: Raja Grafindo Persada, 1998.

Sudirman, Zakat Dalam Pusaran Arus Modernitas, Malang: UIN Malang Press, 2007

Suprayogo, Imam dan Tabroni. Metode Penelitian Sosial Agama, Bandung: Remaja Rosda Karya, 2001.

Sudewo, Eri. Manajemen Zakat Tinggalkan 15 Tradisi Terapkan 4 Prinsip Dasar, Ciputat: Institut Manajemen Zakat, 2004.

Tricahyono, Andi. Wawancara;Tgl 24 Juli 2012. 